\title{
PATHOLOGICAL SPECTRUM OF LESIONS IN NEPHRECTOMY SPECIMENS IN A TERTIARY HOSPITAL
}

\author{
Vishrabdha Pawar ${ }^{1}$, Vaibhav Mane ${ }^{2}$
}

1 Professor, Department of Pathology, Bharati Vidyapeeth Deemed University Medical College and Hospital, Sangli, Maharashtra. ${ }^{2}$ Associate Professor, Department of Pathology, Bharati Vidyapeeth Deemed University Medical College and Hospital, Sangli, Maharashtra.

\begin{abstract}
Kidneys are involved in various pathological processes, some of which may require nephrectomy. Simple nephrectomy is done to remove the nonfunctioning kidney involved by different non-neoplastic conditions. Radical nephrectomies is a standard treatment for localized malignant neoplasms of kidney.

OBJECTIVES: To study the pathological spectrum of various lesions in the nephrectomy specimens and to study the indications of nephrectomy.

MATERIAL AND METHODS: This is a three years retrospective analysis of patients who underwent nephrectomy in a tertiary hospital from Aug. 2012 to Aug. 2015

RESULTS: Of the total 49 nephrectomy specimens $81.63 \%$ (40 cases) had nonneoplastic lesions and $18.36 \%$ (09 cases) were neoplastic. Amongst the non -neoplastic conditions, majority had nonfunctioning kidney due to chronic pyelonephritis and renal calculi. Most of the patients were in $4^{\text {th }}$ to 6 th decade and M: F was 0.88:1. Histopathologically all the malignant tumors found were of Renal cell carcinoma and clear cell was the commonest variant noted.
\end{abstract}

CONCLUSION: Among the conditions that necessitate Nephrectomy are the non-neoplastic lesions like chronic pyelonephritis due to renal calculi.

KEYWORDS: Nephrectomy, Chronic Pyelonephritis.

HOW TO CITE THIS ARTICLE: Vishrabdha Pawar, Vaibhav Mane. "Pathological Spectrum of Lesions in Nephrectomy Specimens in a Tertiary Hospital ". Journal of Evolution of Medical and Dental Sciences 2015; Vol. 4, Issue 89, November 05; Page: $15479-15485$, DOI: $10.14260 /$ jemds/2015/2213.

INTRODUCTION: Kidneys are the vital organs essential for the excretory function. They also have endocrine function by producing renin -angiotensin to control blood pressure and secretion of erythropoietin required for hemopoiesis.(1) They can be involved in various pathological processes. Renal diseases are responsible for great deal of morbidity. In conditions like ESRD and malignant neoplasms surgical removal of kidney [Nephrectomy] is required.(2) Simple nephrectomy is done to remove the irreversibly damaged, nonfunctioning kidneys involved by different benign pathological conditions like extensive renal stone disease, neglected PUJ obstruction. Radical nephrectomy is indicated to treat different malignant neoplastic conditions of the kidney.

In the last few years, there has been growing interest in nephron -sparing surgery or partial nephrectomy to treat the selected cases of localized renal cell carcinoma by open or laparoscopic approach. $(2,3,4)$ The history of partial nephrectomy is a timely story settling important precedents for understanding current and future strategies to treat changing patterns of renal neoplasms.(5) The local disease recurrence is the major drawback of nephron -sparing surgery mostly due to incomplete resection of primary tumor. In this due, radical nephrectomy still remains the gold standard for the treatment of renal neoplasms.(4)

Financial or Other, Competing Interest: None.

Submission 07-10-2015, Peer Review 08-10-2015,

Acceptance 21-10-2015, Published 05-11-2015.

Corresponding Author:

Dr. Vaibhav Mane,

Vaishnavi Pathology Laboratory Shop No.2,

Kore House, Vishrambag Sangli-416415,

(Maharashtra).

E-mail: vaishnavilab@rediffmail.com

DOI:10.14260/jemds/2015/2213
The surgical pathologists should be aware that the nonneoplastic renal lesions are common and often overlooked in tumor nephrectomy. This can be an independent risk factor for developing chronic renal insufficiency in partial nephrectomies.(6)

In developing countries like India in many centers, in rural or semi -urban setup the nephrectomies are still being performed by open surgical techniques.(7,8) In our institute also, laparoscopic urological procedure has not been performed.

There are geographical variations in indications of nephrectomy. The cause of loss of renal function which lead to nephrectomy, also differ between pediatric and adult patients.VUR is the leading cause of nephrectomy, whereas malignancies of kidney and upper urinary tract are the important indications in adults. $(9,10)$

Renal tumors comprise a diverse spectrum of neoplastic lesions that are distinct for children and adults. Accurate diagnosis of most renal tumors is possible only after histopathological evaluation in view of tumor size, histologic subtype, nucleus grade and stage, in case of malignant renal neoplasms. ${ }^{(11,12)}$

The present study was done with the following objectivesTo study the histopathological features of various renal lesions in nephrectomy specimens, to differentiate the non -neoplastic and neoplastic lesions and correlate them with demographic and clinical features and to determine the indications of Nephrectomy.

MATERIAL AND METHODS: A retrospective study carried out in the Department of Pathology in a tertiary hospital. 49 nephrectomy specimens received in the period of August 2012 to August 2015 were studied.

The histopathological reports of these cases were collected from the records of histopathology section. 
The clinical details, radiological findings and provisional diagnosis procured from the medical record department. Corresponding slides were collected and reevaluated for confirmation of the diagnosis.

RESULTS: 49 cases of the Nephrectomy specimens studied were distributed as per the histopathological diagnosis into Non neoplastic lesions, Benign neoplasms and Malignant neoplasms and as per the gender. Majority of the cases were of the nonneoplastic category $40(81.63 \%)$, and neoplastic lesions were $09(18.37 \%)$ of which malignant lesions were $08(16.33 \%)$ and a single case of benign neoplasm (2.04\%). There was a slight female preponderance with 26 cases in all the studied cases (Table 1).

Further the age and sex wise distribution of the lesions with the percentage was done and overall the kidneys were affected in the age group of $4-6^{\text {th }}$ decade (Table 2) The nonneoplastic lesions were further classified as various types of Chronic pyelonephritis associated with hydronephrosis due to renal stones, Acute pyelonephritis and perinephric abscess, PUJ obstruction, Adult polycystic kidneys and Multicystic dysplastic kidney (Table 3) Majority of the nonneoplastic lesions were in the category of chronic pyelonephritis with hydronephrosis due to renal stones (32.5\%). These nonneoplastic conditions were common in the males in the age group of 4-5th decade (Table 4)

A single case of benign neoplasm was found and eight cases were of malignant neoplasms. The malignant lesions were common in the age group of 5-6 th decade (Table 5).

Female preponderance was noted in the neoplastic lesions 66.6\% (Table 6) Patients of nonneoplastic lesions presented with flank pain as the common symptom (85.\%) followed by fever (76.955) and burning micturation (65.55\%) (Table 7).

Painless hematuria was the common (71.40\%) symptom in patients with neoplastic conditions (Table 8) and the location of the neoplasms was in the upper pole (Table 9). The malignant neoplasms were further classified on histopathologiical basis and $50 \%$ of renal cell carcinomas were of clear cell type and a single case of high grade urothelial carcinoma of renal pelvis was found (Table 10).

DISCUSSION: From the literature we have found that there is definitely a geographic variation regarding the indications of nephrectomy.(9) Inspite of the introduction of minimal invasive techniques in urology partial nephrectomies and development of better medical facilities, the total number of nephrectomies performed in every decade in large European centre does not seem to have changed much over last 3 decades from 1960-1990.(10) The reported rates of nephrectomies for malignant conditions from studies in Nigeria and Ghana is $67.31 \%$ and $54.6 \%$ respectively.(12,13)

Two studies from India, Kashmir and Bijapur show that the malignant conditions are the major indication of nephrectomy and that is $89.13 \%$ and $54.5 \%$ respectively.(14,15) The percentage of nephrectomies performed in non - neoplastic conditions is still high in the 3 rd world countries because of the non availability of free health services and of course lack of awareness of the gravity of the disease which results in late presentation.(9)

So in our study of 49 cases of nephrectomy specimens $40(81.63 \%)$ were nonneoplastic conditions and $9(18.37 \%)$ were the cases of malignant neoplasms. Chronic pyelonephritis was the major (61\%) indication of nephrectomy amongst the nonneoplastic conditions.
Our findings are similar to the studies of 85 nephrectomies studied in Saudi Arabia.(16) a study of 88 nephrectomies studied in a tertiary hospital in Darjeeling. (7) 70 nephrectomies studied in a hospital in Manglore.(8) a study of 116 nephrectomies studied in a hospital in Bengaluru.(17) 140 cases studied in a tertiary hospital at Srinagar.(18) a study of 73 nephrectomies studied in Addis Ababa University.(9) and 161 cases studied in Iraq. ${ }^{(19)}$

CONCLUSION: There is high rate of nephrectomy performed for nonneoplastic lesions. Obstructive uropathy due to renal stones, leading to hydronephrosis and chronic pyelonephritis is a common finding in our study. Considering the results of the studies in other developing countries, it is concluded that nonneoplastic conditions of the kidney are still the leading cause for nephrectomy in developing countries. All nephrectomy specimens should be subjected to histopathology examination. Open nephrectomy, which is practiced in our hospital, is safe.

\section{BIBLIOGRAPHY:}

1. Gyton and Hall. Urine formation by the kidneys: I. Glomerular filtration, Renal Blood Flow, and their Control. In:Textbook of Medical physiology; $12^{\text {th }}$ ed: Elsevier Saunder 2011; 303-6.

2. Truong LD, Shen SS, Park MH, Krishnan B. Diagnosing nonneoplastic lesions in nephrectomy specimens. Arch Pathol Lab Med 2009;133:189-200.

3. Leibovich BC, Blute ML, Cheville JC,et al. Nephron sparing surgery for approximately selected renal cell carcinoma between 4 and $7 \mathrm{~cm}$ results in outcome similar to radical nephrectomy. J Urol 2004; 171(3): 1066-70.

4. Kirkali Z. The motion: Open Partial Nephrectomy is the Standard of Care for Small Resectable Solid Renal Mass. Eur Urol 2007; 51(2) : 56.

5. Harry W Herr. A History of Partial nephrectomy for Renal Tumors. J Urol 2005; 173(3): 705-8.

6. Kammi J Henriksen, Shane M. Meehan, Anthony Chang. Nonneoplastic Renal Diseases are Often Unrecognized in adult tumor Nephrectomy Specimens, A review of 246 cases. Am J Surg Pathol. 2007; 31(11): 1703-8.

7. Datta B, Moitra T, Choudhary DN, Halder B. Analysis of 88 nephrectomies in a rural tertiary care centre of India, Saudi J Kidney Dis Transpl 2012; 23: 409-13.

8. Amin NA, Pai P, Upadhyaya K. A Histopathological Spectrum of Nephrectomy Specimens in a Tertiary Hospital in Southern India; Int j Biol Med Res 2015;6(3): 5173-5178.

9. D. Andualem, B.Teklebrihan, C Wuletaw. Indications, Complications and Mortality of Nephrectomy in Tikur Anbesa General specialized Hospital.East and Central African Journal of Surgery. Nov/Dec 2012;17(3):92-97.

10. Kubban AK, Hollins GW, Deane RF. Nephrectomy: Changing indications, 1960-1990, Br J Urol 1994; 74: 2748.

11. Rosai J. Guidelines for handling of most common and important surgical specimens. In: Rosai J, ed. Rosai and Ackerman's Surgical Pathology. 9thed. St Louis: Mosby 2004; pp 2911-77.

12. TA Badmus, AB Salako, FA Arogundade etal: Malignant Renal Tumors in Adults: A Ten-Year Review in a Nigerian Hospital. Saudi j kidney dis transplant 2008;19(1):120126. [Pubmed]. 
13. Kyei MY, Klufio GO, mensah JE, Gyasi RK, Attee SG, Ampadu K. Nephrectomy in adults: Experience at the Korle Bu Teaching Hospital, Accra, Ghana. Saudi J Kidney Dis Transpl 2015; 26: 638-42.

14. Bashir N, Bashir $Y$, Shah $P$, Bhat N, salim O, samoon N, Bashir H, Hussain S, Angmo D, Geelani T, Khan D. Histopathological Study of Renal tumors in resected Nephrectomy Specimens - An Experience from Tertiary Care Centre. National Journal of Medical Research 2015; 5(1) : 25-29.

15. Mahesh Kumar U., Yelikar BR*., Girija Patil, Mahesh H Karigoudar, Pankaj Pande and Patil SB.; Spectrum of Histopathological lesions in Nephrectomy specimens - A two year study in a tertiary care hospital; International Journal of Research in Pharmaceutical and Biomedical Sciences; Vol. 3 (4) Oct - Dec 2012;1787-90.

16. El Malik EM, Memon SR, Ibrahim AL, Al Gizawi A, Ghali AM. Nephrectomy in Adults: Asir Hospital Experience. Saudi J Kidney Dis Transpl 1997;8:423-7.
17. Divyashree B. N., Kusuma venkatesh, Madhusudhan H. R., Hanumantha Raju B. K,' 'Pathological spectrum of Non-Neoplastic Diseases in the Nephrectomy Specimens".Journal of Evidence based Medicine and Healthcare; Volume1, Issue 15, December 15, 2014; page; 1909-1920.

18. Aiman A, Singh K, Yasir M. Histopathological spectrum of lesions in nephrectomy specimens: A five-year experience in a tertiary care hospital, Journal of the scientific Society, 2013, volume 40. issue 3,148-54 .

19. Abdulgafoor S, Abdulkareem, Bashar A, Hassawi, Ziyad Ahmed. Nephrectomy. A Clinicopathological Study. J Am Sci 2015; 11(8): 97-101.

20. Christofer D.M. Fletcher, John N Eble, David J Grignon, Robert H. Young. TUMORS OF THE RENAL PELVIS AND URETER. Diagnostic Histopathology of Tumors; $4^{\text {th }}$ ed/ Vol I, Elsevier Saunders 2013; 604-7.

\begin{tabular}{|c|c|c|}
\hline Study and the study period & Benign \% & Malignant \% \\
\hline Present ( 2012 - 2015)-3 years & 81.63 & 18.37 \\
\hline El Fadil MA, EL Malik et al.(16) (1987-1995)- 8 years & 78 & 22 \\
\hline Bisawajit Datta et al.(7) (2002-2009)- 7 years & 62.5 & 37.5 \\
\hline Ashima Amin et al (2003-2012)- 9 years & 54.2 & 45.7 \\
\hline Divyashri BN et al.(17) (2004-2014)- 10 years & 74.41 & 27.59 \\
\hline Aiffa Aiman et al.(18) (2005-2010)-5 years & 77.2 & 22.8 \\
\hline & & 37 \\
\hline D. Andualem et al.(9) (2009-2011)-2 years & 63 & 22.64 \\
\hline Abdulgafoor et al.(19) (2012-2014) -2 years & 77.36 & \\
\hline Various studies comparing the percentage of Nonneoplastic \& Neoplastic lesions \\
\hline
\end{tabular}

In our study the patients were in the age group of 4-6 th decade. Similar were the findings of Badmus TA et al.(12) who found the patients with the nonneoplastic lesions in $4^{\text {th }}$ decade, Mathew et al.(13) and Bashir $\mathrm{N}$ et al.(14) had majority patients of overall renal lesions in the $5^{\text {th }}$ decade, D Andualem et al.(9) and Aiffa Aiman et al.(18) had the patients in $4^{\text {th }}-5^{\text {th }}$ decade.

Flank pain is the most common presenting symptom (85.5\%) in our study followed by fever (76.95\%), burning micturation $(65.55 \%)$, hematuria and mass in loin (34.2\%). Comparison with other studies having similar findings.

\begin{tabular}{|c|c|c|c|c|c|}
\hline Symptoms & Present & D.Andualem. $^{\mathbf{9}}$ & Kyei MY.13 $^{\mathbf{1 3}}$ & Aiman A.18 $^{\mathbf{1 8}}$ & Divyashri. $^{\mathbf{1 7}}$ \\
\hline Flank mass & $85.5 \%$ & $100 \%$ & $67.9 \%$ & $92 \%$ & $98 \%$ \\
\hline Fever & $76.95 \%$ & $17 \%$ & & $25 \%$ & $67 \%$ \\
\hline Burning micturation & $65.55 \%$ & - & - & $48 \%$ & - \\
\hline Hematuria & $34.2 \%$ & $43.5 \%$ & $24.5 \%$ & $30 \%$ & $37 \%$ \\
\hline Flank mass & $34.2 \%$ & $35.6 \%$ & $50.9 \%$ & $22 \%$ & - \\
\hline
\end{tabular}

Amongst the various renal lesions studied, the major indication of nephrectomy is the nonneoplastic lesions and amongst them variants of Chronic pyelonephritis and Chronic pyelonephritis and hydronephrosis due to renal stones forms the major group (62.5\%). The other variants of chronic pyelonephritis noted are Xanthogranulomatous pyelonephritis and Tuberculous pyelonephritis.

\begin{tabular}{|c|c|c|c|c|c|}
\hline Types of CPN & Present & Aiffa A et al.(8) & $\begin{array}{c}\text { Amin A } \\
\text { et al.(18) }\end{array}$ & $\begin{array}{c}\text { D. Andualem } \\
\text { et al.(9) }\end{array}$ & $\begin{array}{c}\text { Abdulgafoor } \\
\text { et al.(19) }\end{array}$ \\
\hline Nonspecific CPN with Renal calculi & $50 \%$ & $62.8 \%$ & $44.3 \%$ & $51.2 \%$ & $47.82 \%$ \\
\hline Xanthogranulomatous Pyelonephritis & $10 \%$ & $5.7 \%$ & $1.4 \%$ & - & $8 \%$ \\
\hline Tuberculous Pyelonephritis & $2.5 \%$ & - & $4.3 \%$ & $4.1 \%$ & $0.62 \%$ \\
\hline \multicolumn{2}{r|}{ The comparison of percentage of Chronic Pyelonephritic lesions in various studies } \\
\hline
\end{tabular}

In the present study 2(5\%) of MCDK are noted. Similarly Amin A.(8) had noted 10\% cases of MCDK.

$03(7.5 \%)$ cases of Emphysematous pyelonephritis are noted in our study.

$6(15 \%)$ cases of PUJO are noted in our study. Datta B et al.(7) found 25\% cases of PUJO and it was the leading cause of nephrectomy in their study. 
Neoplastic lesions constituted $9(18.37 \%)$ of all the renal lesions with M:F of 0.5:1. We had a single case (11.1\%) of benign lesion of Angiomyolipoma. 08 cases (88.1\%) of renal cell carcinoma are noted.

In our study Upper pole is found to be commonly involved 4 in 9 cases $(44.4 \%)$. These findings are similar to the study of Aiffa A et al.(18) (52\%) and Bashir $\mathrm{N}$ et al.(14) (50.5\%).

In the malignant neoplasms of Renal cell carcinomas the common histological type is the clear cell variant in the present study.

Almost all the neoplastic conditions are diagnosed on CT scan or MRI.

Urothelial carcinomas of the the upper urinary tract are similar to those of the bladder. $5-10 \%$ of urothelial carcinomas arise in the upper tract; they are twice as common as tumors of ureters. 50\% tumors are associated with bladder tumors. These are often misdiagnosed as Pyelonephritis, pyonephrosis. Most invasive carcinomas are high grade.(20) Ours is a urothelial carcinoma of the renal pelvis with squamous differentiation. This case was misdiagnosed as a case of CPN on CT scan.

\begin{tabular}{|c|c|c|c|c|c|}
\hline Variant of RCC & Present & $\begin{array}{c}\text { Kammi J } \\
\text { Henriksen et al.(6) }\end{array}$ & $\begin{array}{c}\text { Abdulgafoor } \\
\text { et al.(19) }\end{array}$ & $\begin{array}{c}\text { Ashima A } \\
\text { et al.(18) }\end{array}$ & $\begin{array}{c}\text { Bashir N } \\
\text { et al.(14) }\end{array}$ \\
\hline Clear cell & $44.4 \%$ & $50 \%$ & $65.38 \%$ & $52.9 \%$ & $60.8 \%$ \\
\hline Chromophobe & $22.2 \%$ & $1.6 \%$ & $15.38 \%$ & $11.8 \%$ & $1.1 \%$ \\
\hline Papillary & $11.1 \%$ & $12 \%$ & $15.38 \%$ & $17.6 \%$ & $8.2 \%$ \\
\hline Urothelial carcinoma of renal pelvis & $11.1 \%$ & $4.1 \%$ & $11.36 \%$ & $2.9 \%$ & - \\
\hline \multicolumn{4}{|l}{ The comparison of various malignant lesions in various studies } \\
\hline
\end{tabular}

\begin{tabular}{|c|c|c|c|c|}
\hline Diagnosis & Male & Female & Total & Percentage \\
\hline Nonneoplastic & 21 & 19 & 40 & 81.63 \\
\hline Benign Tumors & 0 & 1 & 1 & 2.04 \\
\hline Malignant tumors & 2 & 6 & 8 & 16.32 \\
\hline Total & $\mathbf{2 3}$ & $\mathbf{2 6}$ & $\mathbf{4 9}$ & $\mathbf{1 0 0}$ \\
\hline \multicolumn{7}{|c|}{ Table 1: Distribution as per histopathological diagnosis and Gender }
\end{tabular}

\begin{tabular}{|c|c|c|c|c|}
\hline Age (years) & M & F & Total & Percentage \\
\hline $1-10$ & 2 & 1 & 3 & 6.24 \\
\hline $11-20$ & - & 1 & 1 & 2.08 \\
\hline $21-30$ & 2 & - & 2 & 4.16 \\
\hline $31-40$ & 3 & 3 & 6 & 12.24 \\
\hline $41-50$ & 4 & 6 & 10 & 20.8 \\
\hline $51-60$ & 5 & 4 & 9 & 18.72 \\
\hline $61-70$ & 4 & 7 & 11 & 22.88 \\
\hline $71-80$ & 3 & 4 & 7 & 14.56 \\
\hline Total & 23 & 26 & $\mathbf{4 9}$ & \\
\hline \multicolumn{7}{|c|}{ Table 2: Age and sex wise distribution of the lesions } \\
\hline
\end{tabular}

\begin{tabular}{|c|c|c|c|c|c|c|c|c|c|}
\hline Lesion & $1-10$ & 11-20 & $21-30$ & $31-40$ & 41- 50 & $51-60$ & 61-70 & $71-80$ & \\
\hline $\begin{array}{c}\text { Chronic nonspecific } \\
\text { pyelonephritis }\end{array}$ & & & 1 & 2 & 2 & 2 & 1 & & \\
\hline $\begin{array}{l}\text { Chronic pyelonephritis with } \\
\text { hydronephrosis and renal } \\
\text { stones }\end{array}$ & & & 1 & 4 & 3 & 3 & 1 & & \\
\hline $\begin{array}{c}\text { Xanthogranulomatous } \\
\text { Pyelonephritis }\end{array}$ & & & & & & & 3 & 1 & \\
\hline Tuberculous pyelonephritis & & & & & 1 & & & & \\
\hline PUJ obstruction & 1 & 1 & 1 & 2 & 1 & & & & \\
\hline $\begin{array}{c}\text { Emphysematous } \\
\text { pyelonephritis }\end{array}$ & & & & & 2 & 1 & & & \\
\hline $\begin{array}{c}\text { Perinephric abscess and } \\
\text { Pyonephrosis } \\
\end{array}$ & & & & 1 & 1 & & 1 & & \\
\hline $\begin{array}{l}\text { Adult Polycystic kidney } \\
\text { disease }\end{array}$ & & & & 1 & & & & & \\
\hline Multicystic kidney disease & 2 & & & & & & & & \\
\hline Total & 3 & 1 & 3 & 10 & 10 & 6 & 6 & 1 & 40 \\
\hline
\end{tabular}




\begin{tabular}{|c|c|c|c|c|}
\hline Lesion & M & F & Total & Percentage \% \\
\hline Chronic nonspecific pyelonephritis & 5 & 3 & 8 & 20 \\
\hline Chronic pyelonephritis with hydronephrosis and renal stones & 8 & 5 & 13 & 32.5 \\
\hline $\begin{array}{c}\text { Xanthogranulomatous } \\
\text { Pyelonephritis }\end{array}$ & 1 & 3 & 4 & 10 \\
\hline Tuberculous pyelonephritis & - & 1 & 1 & 2.5 \\
\hline PUJ obstruction & 4 & 1 & 5 & 12.5 \\
\hline Emphysematous Pyelonephritis & - & 3 & 3 & 7.5 \\
\hline Perinephric abscess and Pyonephrosis & 2 & 1 & 3 & 7.5 \\
\hline Adult Polycystic kidney disease & - & 1 & 1 & 2.5 \\
\hline Multicystic kidney disease & 1 & 1 & 2 & 5.0 \\
\hline Total & $\mathbf{2 1}$ & $\mathbf{1 9}$ & $\mathbf{4 0}$ & \\
\hline \multicolumn{2}{|c|}{ Table 4: Sex wise distribution of non-neoplastic lesions } \\
\hline
\end{tabular}

\begin{tabular}{|c|c|c|c|c|c|}
\hline Lesion & $31-40$ & $41-50$ & $51-60$ & $61-70$ & $71-80$ \\
\hline Benign neoplasm & 1 & & & & 1 \\
\hline Malignant neoplasm & 1 & 3 & 3 & \\
\hline \multicolumn{7}{|c|}{ Table 5: Age (yrs) wise distribution of neoplastic lesions } \\
\hline
\end{tabular}

\begin{tabular}{|c|c|c|}
\hline Lesion & M & F \\
\hline Benign neoplasm & - & 1 \\
\hline Malignant neoplasm & 3 & 5 \\
\hline Total & 3 & 6 \\
\hline Percentage & $33.4 \%$ & $66.6 \%$ \\
\hline \multicolumn{2}{|c|}{ Table 6: Sex wise distribution of neoplastic lesions } \\
\hline
\end{tabular}

\begin{tabular}{|c|c|c|}
\hline Clinical symptom & Number of Cases & Percentage \% \\
\hline Flank Pain & 30 & 85.5 \\
\hline Hematuria & 12 & 34.2 \\
\hline Fever & 27 & 76.95 \\
\hline Lump in abdomen & 12 & 34.2 \\
\hline Burning Maturation & 23 & 65.55 \\
\hline Vomiting & 13 & 37.05 \\
\hline
\end{tabular}

\begin{tabular}{|c|c|c|}
\hline Clinical symptom & Number of cases & Percentage \% \\
\hline Painless Hematuria & 5 & 71.40 \\
\hline Fever & 4 & 57.14 \\
\hline Lump in abdomen & 2 & 28.57 \\
\hline \multicolumn{2}{|c|}{ Table 8: Clinical symptoms of patients with neoplastic lesions } \\
\hline
\end{tabular}

\begin{tabular}{|c|c|}
\hline Location & Number of cases \\
\hline Entire kidney & 3 \\
\hline Upper pole & 5 \\
\hline Lower pole & - \\
\hline Mid region & 1 \\
\hline \multicolumn{2}{|c|}{ Table 9: Location of tumour in kidney in neoplastic lesions } \\
\hline
\end{tabular}

\begin{tabular}{|c|c|c|}
\hline Type & Number of Cases & Percentage \\
\hline Clear cell & 4 & $50 \%$ \\
\hline Papillary & 1 & $12.5 \%$ \\
\hline Chromophobe & 2 & $25 \%$ \\
\hline Urothelial carcinoma of the renal pelvis & 1 & $12.5 \%$ \\
\hline Total & $\mathbf{8}$ \\
\hline \multicolumn{2}{|c|}{ Table 10: Frequency of Histopathological types of RCC } \\
\hline
\end{tabular}




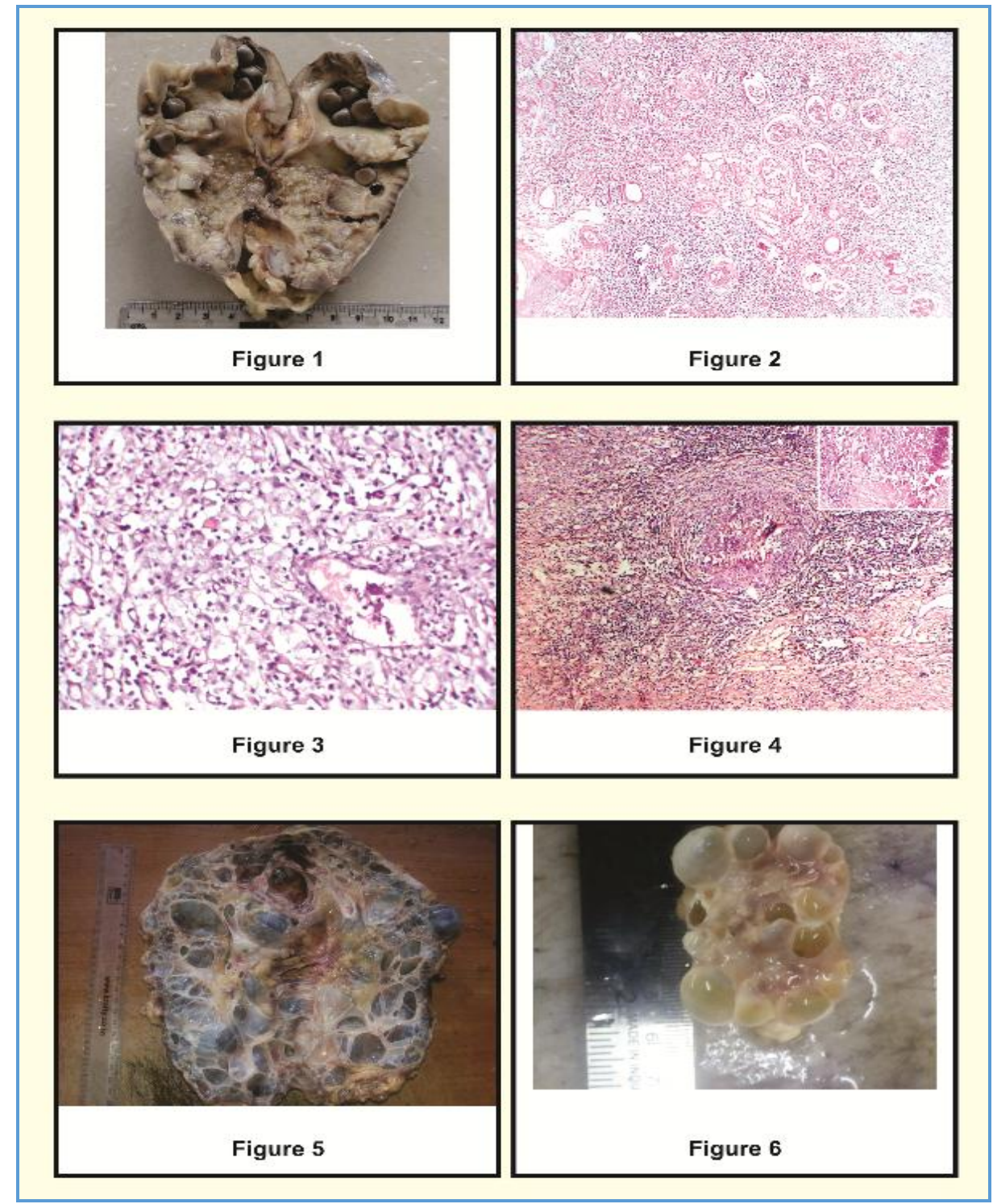

Figure 1: Chronic pyelonephritis: Loss of corticomedullary junction \& multiple renal stones.

Figure 2: (10X, H\&E) - Chronic Pyelonephiritis with diffuse mononuclear Cell infiltration, sclerosed glomeruli and thyroidisation of the tubules.

Figure 3: (10X, H\&E) - Xanthogranulomatous Pyelonephritis with collection of foamy macrophages in the interstitium.

Figure 4: (10X, H\&E) -Tuberculous pyelonephritis with a caseating granuloma \& Langhans giant cell in the inset.

Figure 5: Adult Polycystic Kidney - Cut section shows multiple cysts.

Figure 6: Multicystic kidney disease - Cut section hows multiple cysts having no interconnections. 

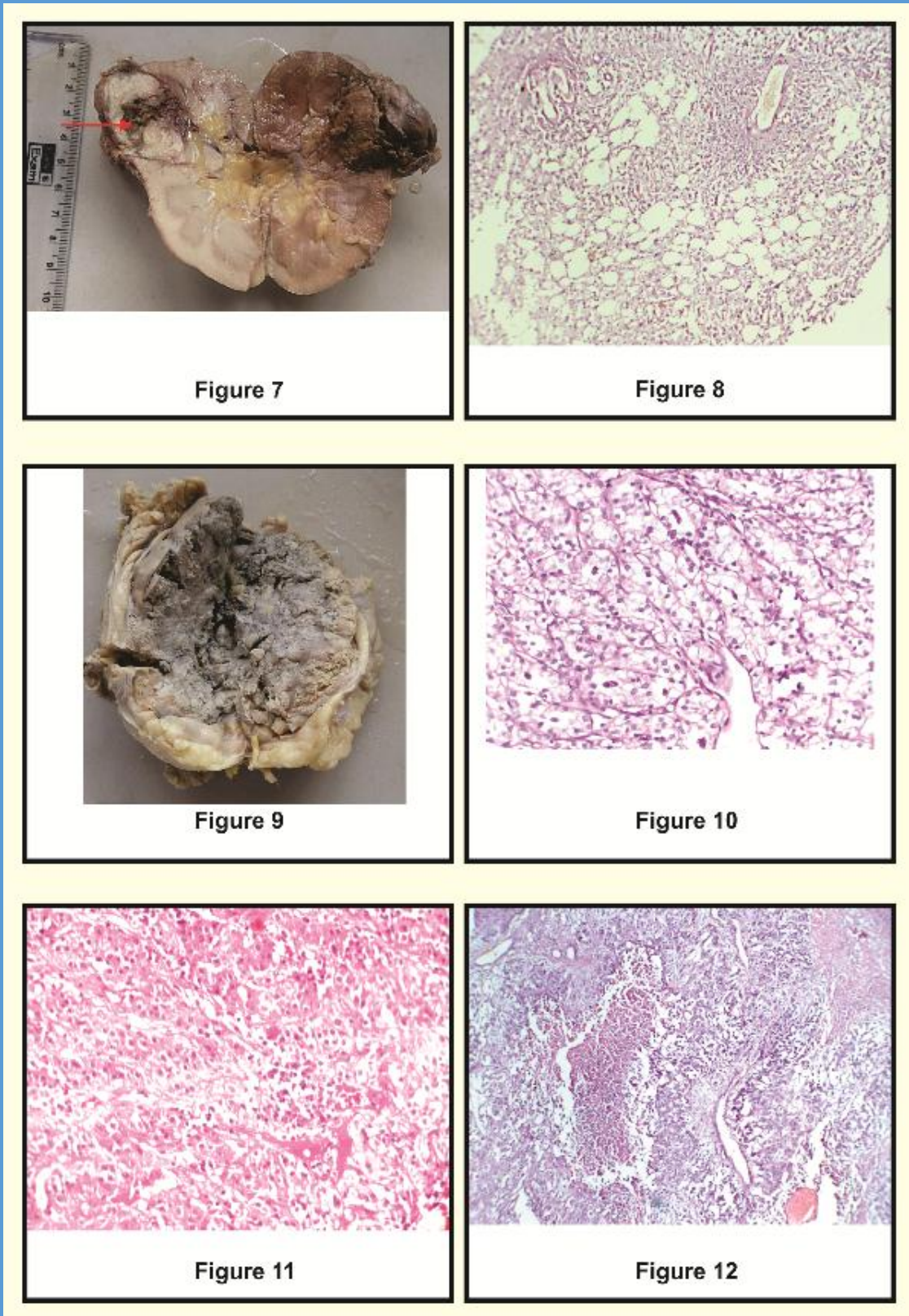

Figure 7: Cut section of Angiomyolipoma located in the upper pole with a grey-white mass with areas of hemorrhage. Figure 8: (10 X H \& E) Angiomyolipoma showing mixture of fat cells, large blood vessels and whorls of smooth muscles. Figure 9: Cut section of Renal cell carcinoma- Huge renal mass with a variegated appearance.

Figure 10: (40X, H\&E) Renal Cell Carcinoma- Clear Cell Type.

Figure 11: (10X, H\&E) Renal Cell Carcinoma - Chromophobe Type.

Figure 12: (10X, H\&E) Renal cell carcinoma- Invasive Urothelial carcinoma with large areas of necrosis. 